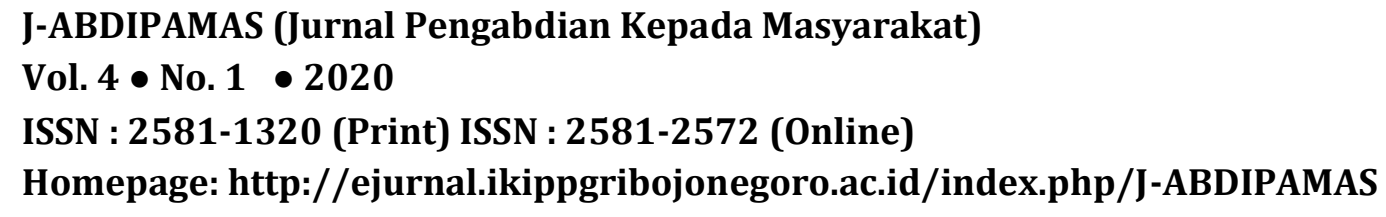

ISSN : 2581-1320 (Print) ISSN : 2581-2572 (Online)

Homepage: http://ejurnal.ikippgribojonegoro.ac.id/index.php/J-ABDIPAMAS

\title{
PEMANFAATAN SAMPAH RUMAH TANGGA BERBASIS PENGELOLAAN BANK SAMPAH DI SEKOLAH
}

\author{
Abdul Rahim ${ }^{1}$, Ibrahim ${ }^{2}$, Nur Indah Mansyur ${ }^{3}$ \\ 1Universitas Borneo Tarakan. Email: rahim@borneo.ac.id \\ 2Universitas Borneo Tarakan. Email: ibrahimborneo77@gmail.com \\ 3Universitas Borneo Tarakan. Email: nurindah.mansyur@gmail.com
}

\begin{abstract}
This community service activity aims to provide education about household waste utilization through waste banks in schools. The method used in this community service activity is training and mentoring on how to use waste and manage waste through a waste banks. The results of this activity show: (1) increasing students' insights about household waste utilization by composting and liquid fertilizer training; (2) students and schools get experience on waste bank management; (3) through the management of a waste banks, transactions that occur reach Rp.2,231,030 in SMP Negeri 2, and Rp. 138,000 at SDN 08 Tarakan. The evaluation of this activity is based on the number of customers and the value of the transaction. So the model of managing a waste banks in junior high schools can be applied, but it is not recommended for primary schools in Tarakan City.
\end{abstract}

Keyword: Waste, School, waste banks.

\begin{abstract}
ABSTRAK
Kegiatan pengabdian ini bertujuan untuk memberikan edukasi tentang pemanfaatan sampah rumah tangga melalui bank sampah di sekolah. Metode yang digunakan dalam kegiatan pengabdian ini yakni pelatihan dan pendampingan bagaimana pemanfaatan sampah dan pengelolaan sampah melalui bank sampah. Hasil kegiatan ini menunjukkan: (1) meningkatnya wawasan siswa tentang pemanfaatan sampah rumah tangga dengan pelatihan kompos dan pupuk cair; (2) siswa dan pihak sekolah mendapatkan pengalaman tentang pengelolaan bank sampah; (3) melalui pengelolaan bank sampah, transaksi yang terjadi mencapai Rp 2.231.030 di SMP Negeri 2, dan Rp. 138.000 di SDN 08 Tarakan. Evaluasi kegiatan ini berdasarkan jumlah nasabah dan nilai transaksi. Jadi model pengelolaan bank sampah di SMP dapat diterapkan, namun tidak direkomensasikan untuk sekolah dasar di Kota Tarakan.
\end{abstract}

Kata Kunci: Sampah, Sekolah, Bank Sampah.

\section{PENDAHULUAN}

Tarakan secara geografis terletak antara $3^{0} 14^{\prime} 23^{\prime \prime}-3^{0} 26^{\prime} 37^{\prime \prime}$. Lintang Utara dan $117^{0} 30^{\prime} 50^{\prime \prime}$ - $117^{0} 40^{\prime} 12^{\prime \prime}$ Bujur Timur. Daerah ini merupakan daerah yang berada di Bagian Utara Propinsi Kalimantan Timur berdekatan dengan Negara Malaysia bagian Sabah. Kota Tarakan terdiri dari 2 (dua) pulau, yaitu Pulau Tarakan dan Pulau Sadau dengan luas daratan $250.80 \mathrm{Km}^{2}$ dan panjang laut 3 mil yang mengelilinginya seluas 406,53 km² (BPS Tarakan, 2018).

Seiring dengan pertambahan penduduk di Kota Tarakan, maka terjadi peningkatan volume sampah dari waktu ke waktu. Beberapa hasil penelitian menunjukkan bahwa timbulan sampah Kota Tarakan pada tahun 2015 mencapai 0.265 kg per orang per hari 
dengan jumlah penduduk 227.200, maka timbulan sampah mencapai 66 Ton. Sedangkan, pada tahun 2018 penduduk berjumlah 262.025 jiwa maka produksi sampah mencapai mencapai 69 ton per hari (BPS Kota Tarakan, 2015; BPS Kota Tarakan, 2019; Masterplan Persampahan Kota Tarakan, 2015).

Sistem Pengelolaan Sampah dapat dikelola oleh individu, kelompok masyarakat (Putri, 2010 dan Nuryani, 2012). Menurut Bappeda (2011) perilaku masyarakat dari membuang sampah menjadi memanfaatkan sampah masih belum tersosialisasi dan terlaksana dengan baik. Selain itu, terdapat program tabungan lingkungan atau bank sampah di sekolah yang bertujuan untuk memberikan pemahaman sejak dini tentang pemanfaatan sampah di kota Tarakan sejak tahun 2015 (Fahrien 2019). Namun demikian, hasil observasi di lapangan menunjukkan terdapat berbagai kendala dalam mewujudkan inovasi tabungan lingkungan di sekolah tersebut, diantaranya; (1) terbatasnya pengetahuan tentang pemanfaatan sampah, (2) minimnya pengalaman siswa dan pihak sekolah dalam pengelolaan tabungan lingkungan atau bank sampah, dan (3) miniminya sarana dan prasarana dalam mengimpelentasikan tabungan lingkungan di sekolah tersebut.

Berdasarkan situasi dan kondisi diatas, isu pokok dari mengatasi permasalahan sampah, yakni bagaimana memberikan edukasi mengelola sampah menjadi bermanfaat dan upaya keterlibatan masyarakat dalam mengatasi sampah di Kota Tarakan, khususnya siswa sekolah dasar dan menengah.

Tujuan kegiatan pengabdian ini adalah melakukan pelatihan contoh pemanfaatan atau pengelolaan sampah, serta pemanfaatan sampah berbasis tabungan lingkungan atau bank sampah di sekolah (Studi Kasus SMP Negeri 2 Tarakan dan SDN 018 Kota Tarakan).

\section{METODE PELAKSANAAN}

Lokasi kegiatan di Kota Tarakan provinsi Kalimantan Utara yakni: (1) SMP Negeri 2 Tarakan, dan (2) SDN 018 Kota Tarakan. Sasaran kegiatan yakni siswa-siswi, guru sekolah pembina kegiatan kesiswaan, dan pengurus sekolah.

Metode yang digunakan adalah melakukan kegiatan pengelolaan sampah di sekolah, dengan model pengelolaan bank sampah (Gambar 1). Selain itu, metode kegiatan yang telah dilaksanakan yakni: (1) pelatihan pengelolaan sampah; (2) pendampingan pembentukan kelompok siswa yang terkait dengan pendidikan lingkungan (ekstraqurikuler lingkungan); (3) membentuk dan mengembangkan bank sampah (tabungan lingkungan) di sekolah. 


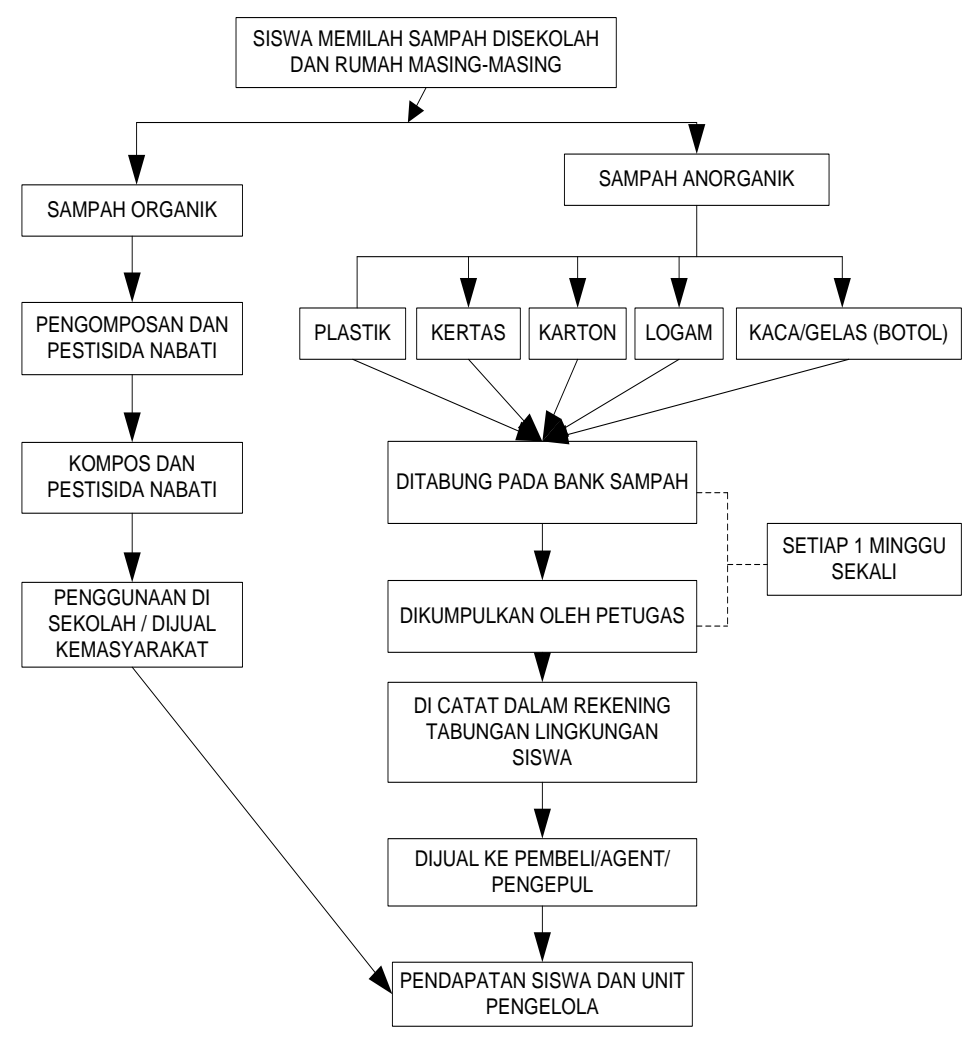

Gambar 1. Model pengelolaan bank sampah di sekolah

\section{HASIL DAN PEMBAHASAN}

\section{Pelatihan Pengelolaan Sampah}

Peserta yang mengikuti kegiatan pengolahan sampah yakni siswa di SMP Negeri 2 Tarakan. Sedangkan materi yang diberikan yakni pemanfaatan sampah dengan menggunakan teknologi pembuatan kompos dan mol (pupuk cair). Siswa sangat antusias mengikuti kegiatan tersebut. Kegiatan ini juga menghasilkan kompos yang digunakan untuk taman yang ada di sekolah. Kendala pada pembuatan kompos yakni terbatasanya ruang atau halaman yang dipergunakan untuk pengembangan produk dari pengolahan sampah.
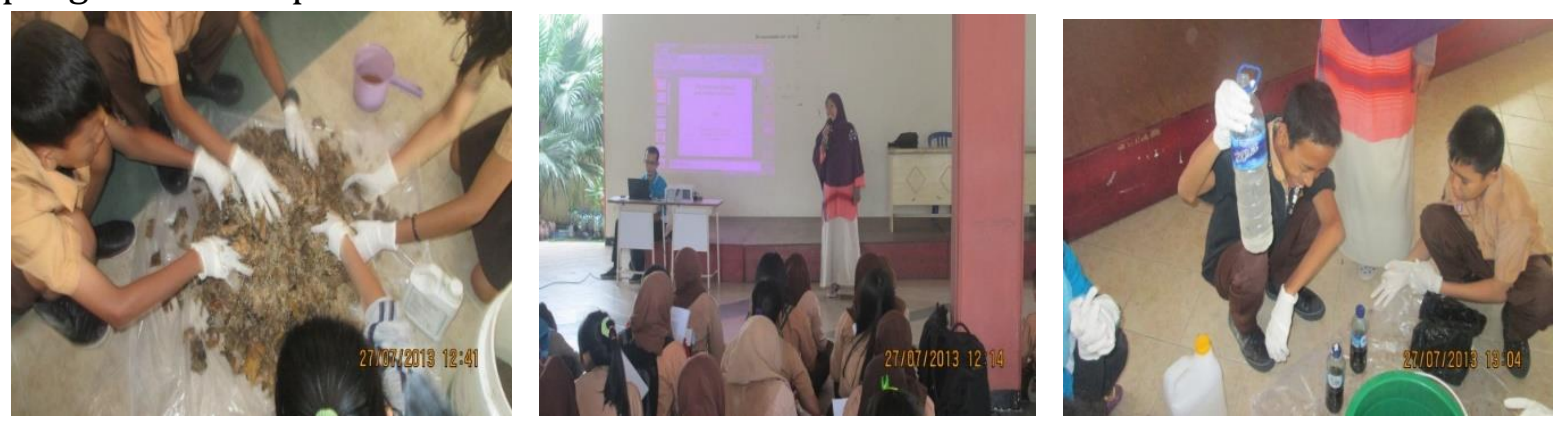

Gambar 2. Narasumber (Anggota IbM, bu Nur Indah Mansyur) sedang menyampaikan materi tentang pemanfaatan sampah dengan menggunakan teknologi pembuatan kompos dan MoL (pupuk cair) 
Pendampingan pengelolaan bank sampah (tabungan lingkungan) di sekolah

Penabungan sampah (tabungan lingkungan) dilakukan dengan langkah siswa memilah sampah organik dan anorganik di rumah masing-masing. Langkah selanjutnya, siswa membawa ke petugas (mahasiswa pendamping dan siswa) di bank sampah sekolah (yang dibentuk pada program pengabdian). Berikutnya, di dilakukan penimbangan dan pencatatan dalam rekening penabung (siswa). Langkah terakhir, sampah langsung dibawa (mahasiswa pendamping) untuk dijual ke pembeli/agen/ pengepul.
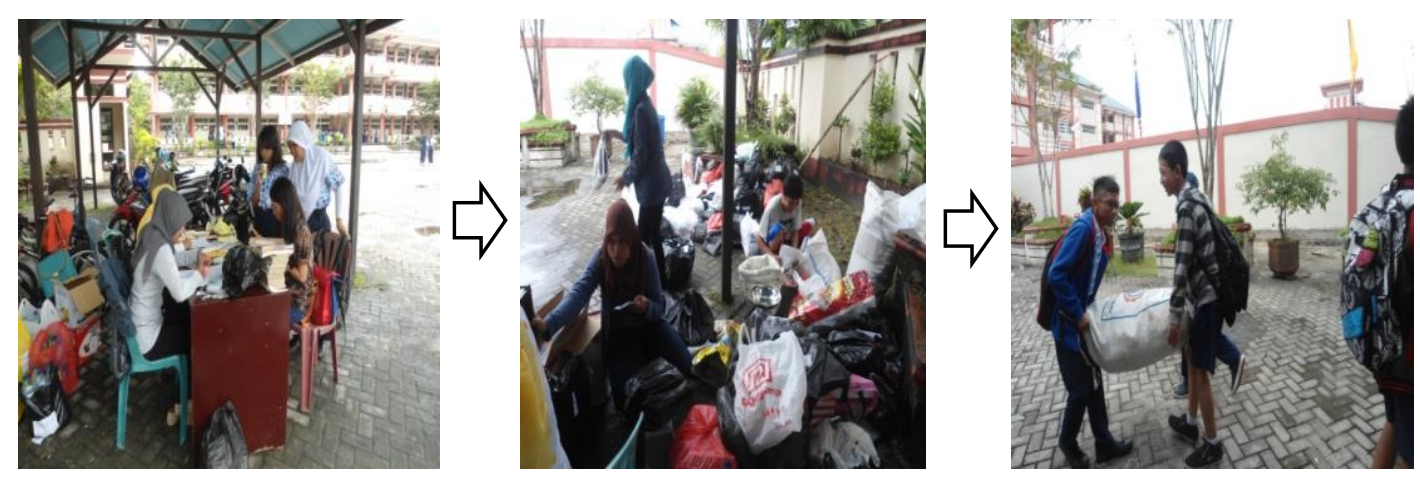

Gambar 3. Situasi proses atau tahapan pelayanan Bank Sampah

Jenis sampah yang ditabung merupakan sampah yang telah disepakati dengan pengepul, diantaranya kardius, botol plastik, buku bekas, kaleng soft drink, dan gelas plastik.
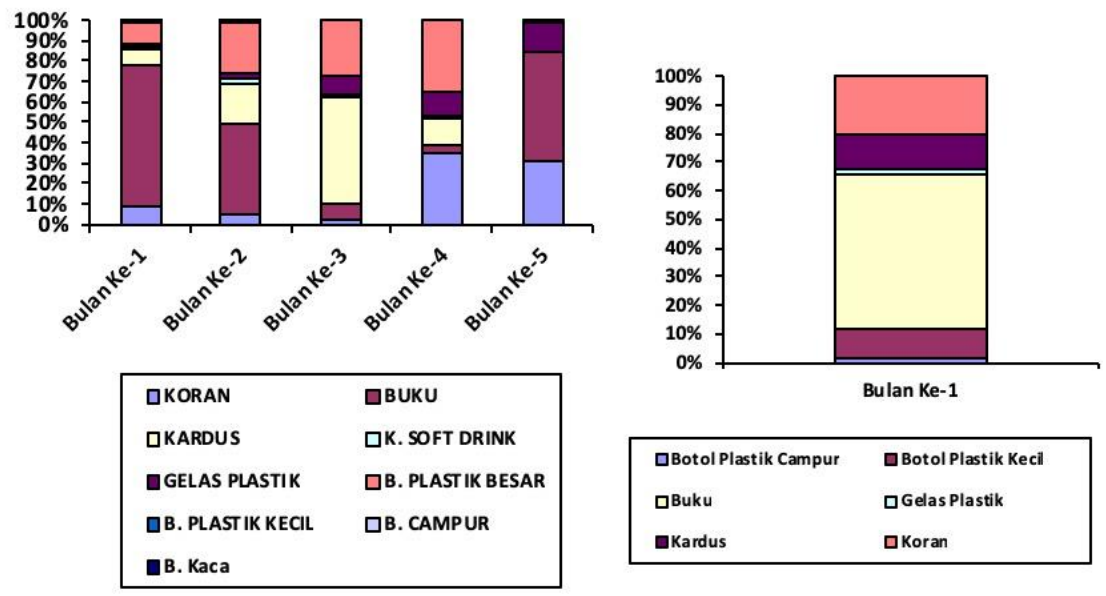

Gambar 4. Jenis tabungan bank sampah di SMP Negeri 2 dan SDN 018 Kota Tarakan 
Siswa di SMP Negeri 2 yang berpastisipasi sebanyak 123 siswa, dan 105 siswa di SDN 018 Tarakan.

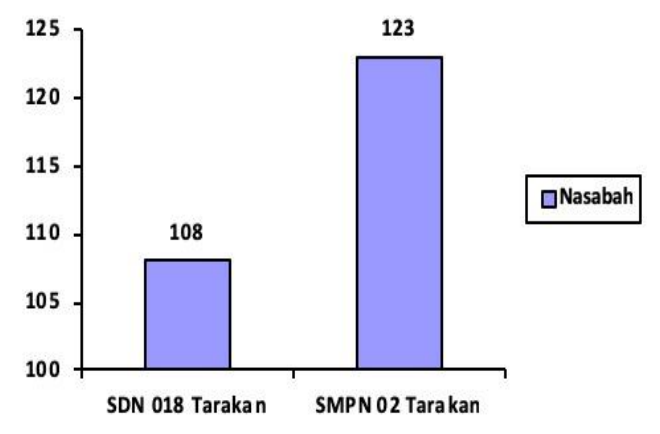

Gambar 5. Nasabah (siswa) bank sampah

Mitra SMPN 2 Tarakan yang terlibat dalam transaksi yang terjadi selama pelaksanaan program mengalami fluktuasi dan total keseluruhan transaksi sebesar 988 kali, dan transaksi tertinggi pada tanggal transaksi bulan pertama, dan terendah pada transaksi bulan terakhir setelah program akan selesai. Berikut ini disajikan grafik transaksi yang terjadi selama pelaksanaan program hingga bulan ke-5 transaksi.

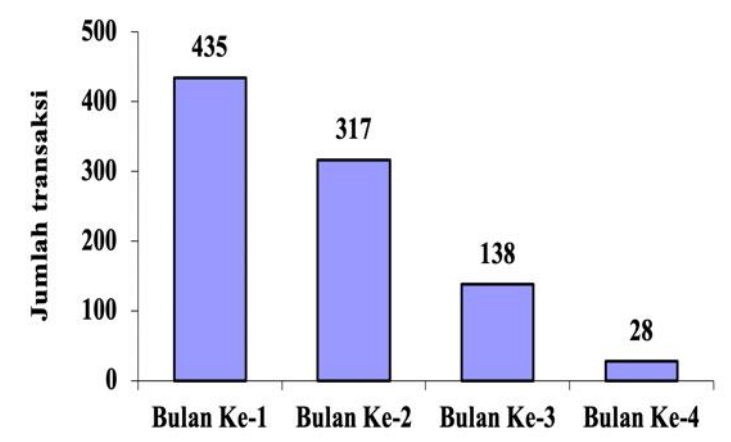

Gambar 6. Jumlah transaksi pelayanan Bank Sampah di SMP Negeri 2 Tarakan

Nilai dalam rupiah transaksi yang dilakukan di SMPN 2 Tarakan, berdasarkan jenis tabungan pada periode bulan pertama sebesar Rp. 1.115 .640 (satu juta seratus lima belas ribu rupiah) dan September sebesar Rp. 688.500 (enam ratus delapan puluh delapan ribu lima ratus rupiah).

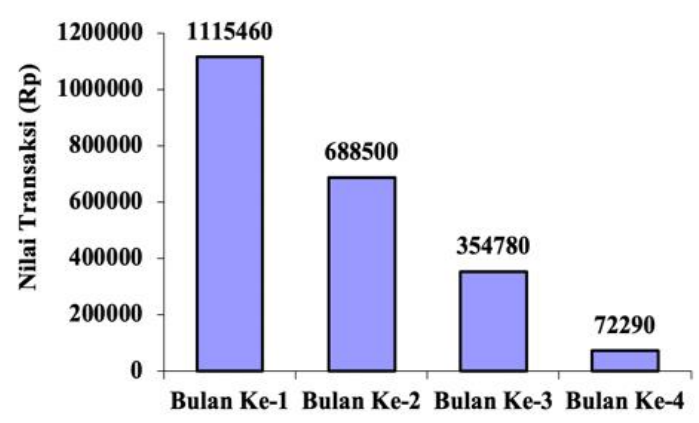

Gambar 7. Nilai transaksi (Rp) pada pelayanan Bank Sampah di SMP Negeri 2 Tarakan 
Mitra SDN 018 Tarakan yang terlibat dalam transaksi yang terjadi hanya pada bulan pertama dengan jumlah transaksi sebesar 292 kali (Gambar 7)

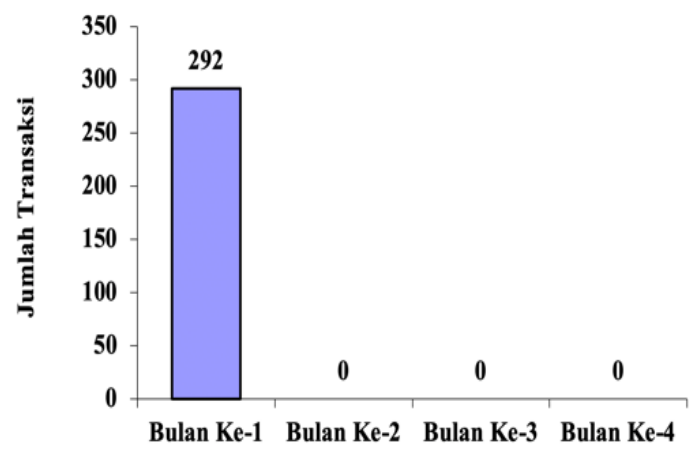

Gambar 8. Jumlah transaksi pelayanan Bank Sampah di SD Negeri 018 Tarakan

Nilai dalam rupiah transaksi yang dilakukan di SDN 018 Tarakan sangat kecil, berdasarkan jenis tabungan pada periode bulan pertama hanya sebesar Rp. 139.800 (seratus tiga puluh Sembilan delapan ratus rupiah)

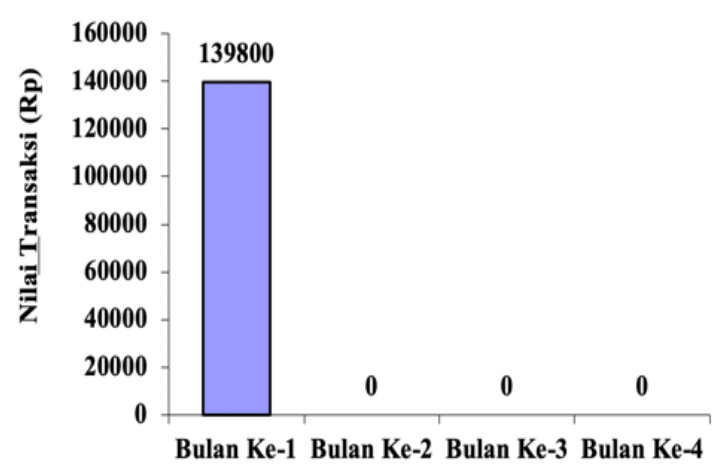

Gambar 9. Nilai transaksi (Rp) pelayanan bank sampah di SDN 018 Tarakan

\section{SIMPULAN}

Kegiatan pengabdian masyarakat yang dilakukan di SMP Negeri 2 Tarakan dan SDN 018 Tarakan telah dilaksanakan sesuai dengan model pengelolaan bank sampah di sekolah. Siswa sangat bersemangat mengikuti kegiatan sosialisasi, pelatihan, pendampingan dan evaluasi. Kegiatan ini dapat meningkatkan pengetahuan siswa dan kesadaran siswa akan manfaat dari sampah rumah tangga. Sehingga, siswa menilai sampah bukan barang tidak berguna atau sampah memiliki nilai ekonomis. Namun, khusus anak Sekolah Dasar, model pengelolaan bank sampah belum dapat diterapkan dengan baik, sehingga perlu cara lain untuk mengenalkan manfaat atau nilai sampah.

\section{UCAPAN TERIMA KASIH}

Penulis mengucapkan terimakasih kepada Direktorat Penelitian dan Pengabdian kepada Masyarakat Dikti yang berkenan memberikan Hibah Ipteks Bagi Masyarakat. Serta, Rektor Universitas Borneo Tarakan, Ketua LPPM Universitas Borneo, Dekan Fakultas Pertanian, Dekan Fakultas Keguruan dan Ilmu Pendidikan Universitas Borneo, Kepala Sekolah SMPN 02 Tarakan, Kepala Sekolah SDN 018, beserta seluruh anggota yang turut serta mendukung pelaksanaan kegiatan pengabdian ini. 


\section{DAFTAR RUJUKAN}

Badan Pusat Statistik Kota Tarakan. (2015). Kota Tarakan dalam Angka. Tarakan: BPS Kota Tarakan

Badan Pusat Statistik Kota Tarakan. (2019). Kota Tarakan dalam Angka. Tarakan: BPS Kota Tarakan

Badan Perencanaan dan Pembangunan Daerah Kota Tarakan. (2011). Pemberdayaan Ekonomi Masyarakat Melalui Pengelolaan Bank Sampah. Tarakan: Bappeda Kota Tarakan

Fahrien, M. (2019). Inovasi Kebijakan Pemerintah Kota Tarakan dalam Pengelolaan Sampah (Studi Tentang Program Tabungan Lingkungan). Malang: UM Malang.

Nuryani, A. (2012). Peranan Bank Sampah Gemah Ripah Terhadap Kesemptan Kerja dan Pendapatan Keluarga di Kecamatan Bantul Kabupaten Bantul Provinsi Daerah Istimewa Yogyakarta. Yogjakarta: Fakultas Ekonomi UNY.

Pemerintah Kota Tarakan. (2015). Masterplan Persampahan Kota Tarakan. Tarakan: Pemkot Tarakan

Putri, A. N. (2010). Partisipasi Perempuan dalam Pengelolaan Sampah Melalui "Bengkel Kerja Kesehatan Lingkungan Berbasis Masyarakat" Di Dusun Badengan Bantul. Fakultas Sosial Politik: Surakarta: UNS 
44 J-Abdipamas, Vol. 4, No. 1 April, 2020 